\title{
Effects of Lifestyle Measures, Antiobesity Agents, and Bariatric Surgery on Serological Markers of Inflammation in Obese Patients
}

\author{
Konstantinos Tziomalos, Hariklia V. Dimitroula, Niki Katsiki, \\ Christos Savopoulos, and Apostolos I. Hatzitolios
} First Propedeutic Department of Internal Medicine, Medical School, Aristotle University of Thessaloniki,
AHEPA Hospital, 54646, Thessaloniki, Greece

Correspondence should be addressed to Konstantinos Tziomalos, ktziomalos@yahoo.com

Received 1 December 2009; Revised 25 January 2010; Accepted 6 February 2010

Academic Editor: Giuseppe Matarese

Copyright (C) 2010 Konstantinos Tziomalos et al. This is an open access article distributed under the Creative Commons Attribution License, which permits unrestricted use, distribution, and reproduction in any medium, provided the original work is properly cited.

\begin{abstract}
Overweight and obesity are highly prevalent in developed countries and are also becoming more frequent in the developing world. Overweight and obese patients have elevated levels of several inflammatory markers and this inflammatory state might contribute to their increased vascular risk. We summarize the effects of lifestyle changes, antiobesity agents, and bariatric surgery on serological inflammatory markers in overweight and obese patients. Most studies showed a decrease in inflammation with all 3 interventions. However, it remains to be established whether the decrease in inflammatory markers induced by lifestyle changes or (where indicated) with antiobesity agents or bariatric surgery will translate into reduced vascular morbidity and mortality in overweight and obese patients.
\end{abstract}

\section{Introduction}

Overweight and obesity are highly prevalent in developed countries [1]. Approximately one third of the US population is obese and two thirds are overweight [1]. The prevalence of obesity is also increasing in developing countries [2]. This epidemic of overweight and obesity has major implications, since both overweight and obesity are independently associated with increased mortality [3-5].

Adipose tissue is not metabolically inert but synthesizes and secretes proinflammatory mediators, including interleukin 6 (IL-6) [6-9], tumor necrosis factor $\alpha$ (TNF $\alpha)$ [7, $10,11]$, IL-8 [7], and monocyte chemoattractant [protein 1] (MCP-1) $[12,13]$. Several studies reported that high sensitivity C-reactive protein levels are elevated in overweight and obese patients [14-26]. Compared with lean subjects, overweight and obese patients also have higher levels of IL6 [9, 19, 24, 26-28], TNF $\alpha$ [24, 26-30], MCP-1 [27], as well as of other markers of inflammation, including IL-8 [31,32], IL-18 [33], soluble TNF receptor-2 (sTNFR2) [27, 34, 35], soluble E-selectin [26, 36, 37], soluble intercellular adhesion molecule-1 (sICAM-1) [18, 26, 27, 34, 36-38], and soluble vascular cell adhesion molecule-1 (sVCAM-1) $[26,36]$. In obese patients, inflammatory markers correlate with visceral adipose tissue mass $[20,21,27,33,34,39-41]$ and with waist circumference, an index of visceral adiposity $[17,21-$ $23,27,32,35,39]$.

The activation of inflammation that is present in obesity might contribute to the increased vascular morbidity and mortality of these patients, since elevated levels of inflammatory markers are associated with increased vascular risk [42-46]. In this review, we summarize the effects of lifestyle changes, antiobesity agents, and bariatric surgery on serological inflammatory markers in obese patients.

\section{Lifestyle Measures}

Lifestyle measures are the cornerstone of the management of obesity [47]. In randomized controlled studies, diet and 
exercise reduced the risk of type 2 diabetes mellitus (T2DM) in overweight patients with impaired glucose tolerance (IGT) $[48,49]$. In observational studies, weight loss achieved with lifestyle changes was associated with reduced incidence of coronary heart disease (CHD) [50] and with lower all-cause mortality [51].

Several studies evaluated the effects of diet and exercise alone or in combination on inflammatory markers in obese patients.

2.1. Diet Alone. Several small studies $(n=11-100)$ assessed the effects of low-calorie, very low-calorie, low-fat, or low-carbohydrate diets on inflammatory markers in obese patients (Table 1) $[20,22,28,52-75]$. The duration of the intervention ranged from 3 weeks to 17 months [20, 22, 28, 52-75]. The majority of studies noted a significant decrease in CRP after weight loss induced by dietary modification in otherwise healthy overweight or obese adults $[20,22,52$, $54,56-60,62,64-68,70,72-75]$, in obese patients with the metabolic syndrome [69], in overweight patients with raised triglycerides (TG) [55], in severely obese patients [71], or in obese patients with T2DM [53]. In some studies, the magnitude of decrease in hsCRP levels was linearly correlated to the amount of weight loss [20, 22,67]. Only few reports did not record a significant fall in hsCRP concentration after weight loss $[28,63]$.

Furthermore, several studies compared the effects of different diets on inflammatory markers [52-54, 56, 57, $59,62,65-68,70-73]$. Heald et al. reported a significant $24 \%$ decrease in serum hsCRP levels after 3 months of replacement of high-fat foods with reduced-fat alternatives [59]. In another study, a carbohydrate restricted diet (CRD) with daily intake of eggs decreased hsCRP levels compared with a CRD without eggs, indicating that eggs significantly contribute to the anti-inflammatory effects of CRD possibly due to the antioxidant lutein which is present in eggs and modulates certain inflammatory responses [70]. A low-glycemic-load diet was also associated with a significantly greater improvement in serum hsCRP concentration compared with a low-fat diet (48 versus 5\%) despite the similar weight loss in both diets [68]. In contrast, a more recent study reported a greater fall in hsCRP levels after a high-carbohydrate, low-saturated-fat diet compared with an isocaloric very-low-carbohydrate, high-saturatedfat diet, even though the latter group lost more weight and abdominal fat [62]. However, most studies comparing diets of different composition reported a similar decrease in hsCRP concentration among groups, suggesting that the weight loss per se rather than the dietary composition is the primary determinant of the fall in inflammatory markers during diet $[52-54,56,57,65-67,71-73]$.

The effect of dietary intervention on other inflammatory markers is more controversial. Some studies reported a reduction in serum TNF $\alpha$ levels with diet $[31,72,74,76,77]$ while others have not $[28,70,75]$. Similarly, serum IL-6 levels fell after diet-induced weight loss in some $[28,31,72,76]$, but not all studies $[60,74]$. Regarding the effects of diet on IL-8, a significant reduction [76], increase [31], or no change [70] has been reported. In addition, caloric restriction did not affect circulating levels of the anti-inflammatory cytokine IL-10 [78]. However, limited data suggest that diet-induced weight loss is associated with a proportional reduction in IL-18 [33] and IL-20 levels [79]. Weight loss by caloric restriction also induces significant decreases in sICAM-1 [36, $52,55,61,62,72]$ and sVCAM-1 levels [36, 61, 80]. Only one study reported no change in sICAM-1 and sVCAM-1 levels [70] and another study reported an increase in sVCAM-1 levels [62].

The conflicting results mentioned above could be attributed to the differences in baseline characteristics of the studied population that might influence inflammatory markers (i.e., age, gender and coexisting diseases), the brief duration of the intervention, the insufficient sample size, or the degree of body weight reduction. Overall, the greatest reductions in serological markers of inflammation were observed in studies where an at least $10 \%$ weight loss was achieved.

Interestingly, recent studies demonstrated that brief periods of reduced food intake can increase resistance to ischemia reperfusion injury in rodents and modify circulating levels of pro-inflammatory agents in humans $[81,82]$. The effects of short-term interventions on inflammation appear to be mostly due to the calorie restriction and negative energy balance whereas in long-term interventions weight loss and adipose mass reduction also contribute to the suppression of inflammation. However, existing studies do not show a major difference between the effects of short and long terms of calorie restriction on the levels of inflammatory markers. The 2 studies that did not report an effect of diet on hsCRP levels lasted for 3 weeks and 3 months, respectively [28, 63]. In addition, both short- and long-lasting dietary interventions ( 3 weeks to 17 months) induced a reduction in hsCRP levels in several studies $[20,22,52-60,62,64-75]$.

2.2. Exercise Alone. A number of small studies $(n=$ 8-199) evaluated the effects of exercise training, resistance training, or aerobic exercise training for 2-12 months on inflammatory markers (Table 1) [35, 83-93]. Some [83-87] but not all [88-90] studies reported a significant reduction in serum hsCRP levels. Interestingly, body weight changed only slightly in some studies that reported a significant fall in hsCRP levels [83-85]. Limited data exist on the impact of exercise on other markers of inflammation. Serum TF $\alpha$ levels fell after aerobic exercise training in most $[35,87,91]$ but not all studies [84]. In contrast, serum IL-6 levels did not change with exercise in most reports $[83,85,89]$ and fell only in 1 study [90]. The concentration of IL-10, an anti-inflammatory cytokine, increased after 6 months of aerobic exercise in overweight patients with T2DM [84] and serum IL-18 concentration decreased in the same study [84], but remained unchanged in another [93]. In addition, sICAM-1 and sVCAM-1 levels were not affected after one year of resistance training [85]. In a recent controlled exercise training intervention, 189 overweight and mildly obese patients were randomized to 6 months of inactivity or 1 of 3 types of aerobic exercise training regimens: lowamount/moderate intensity, low-amount/vigorous intensity, and high-amount/vigorous intensity [92]. Despite a mean 
TABLE 1: Effects of lifestyle measures, antiobesity agents, and bariatric surgery on serological markers of inflammation in obese patients.

\begin{tabular}{|c|c|c|c|}
\hline Intervention & Marker of inflammation & Effect & Reference \\
\hline \multirow{19}{*}{ Diet alone } & hsCRP & $\downarrow$ & $\downarrow:[20,22,52-60,62,64-$ \\
\hline & & or no effect & $75,115,118]$ \\
\hline & & & no effect: $[28,63]$ \\
\hline & $\mathrm{TNF} \alpha$ & $\downarrow$ & $\downarrow:[31,72,74,76,77]$ \\
\hline & & or $\uparrow$ & $\uparrow:[117]$ \\
\hline & & or no effect & no effect: $[28,70,75,115,118]$ \\
\hline & IL-6 & $\downarrow$ & $\downarrow:[28,31,72,76,115]$ \\
\hline & & or no effect & no effect: $[60,74]$ \\
\hline & IL-8 & $\downarrow$ & $\downarrow:[76]$ \\
\hline & & or $\uparrow$ & $\uparrow:[31]$ \\
\hline & & or no effect & no effect: [70] \\
\hline & IL-10 & No effect & {$[78]$} \\
\hline & IL-18 & $\downarrow$ & {$[33]$} \\
\hline & IL-20 & $\downarrow$ & {$[79]$} \\
\hline & sICAM-1 & $\downarrow$ & $\downarrow:[36,52,55,61,62,72]$ \\
\hline & & or no effect & no effect: $[70]$ \\
\hline & sVCAM-1 & $\downarrow$ & $\downarrow:[36,61,80]$ \\
\hline & & or $\uparrow$ & $\uparrow:[62]$ \\
\hline & & or no effect & no effect: [70] \\
\hline \multirow{12}{*}{ Exercise alone } & hsCRP & $\downarrow$ & $\downarrow:[83-87]$ \\
\hline & & or no effect & $\begin{array}{l}\text { no effect: } \\
{[88-90,92,115,116,118]}\end{array}$ \\
\hline & $\mathrm{TNF} \alpha$ & $\downarrow$ & $\downarrow:[35,87,91]$ \\
\hline & & or $\uparrow$ & $\uparrow:[117]$ \\
\hline & & or no effect & $\begin{array}{l}\text { no effect: } \\
{[84,92,115,116,118]}\end{array}$ \\
\hline & IL-6 & $\downarrow$ & $\downarrow:[90]$ \\
\hline & & or no effect & $\begin{array}{l}\text { no effect: } \\
{[83,85,89,92,115,116]}\end{array}$ \\
\hline & IL-10 & $\uparrow$ & {$[84]$} \\
\hline & IL-18 & $\downarrow$ & $\downarrow:[84]$ \\
\hline & & or no effect & no effect: [93] \\
\hline & sICAM-1 & No effect & {$[85]$} \\
\hline & sVCAM-1 & No effect & {$[85]$} \\
\hline \multirow{13}{*}{ Combination of diet and exercise } & hsCRP & $\downarrow$ & $\begin{array}{l}\downarrow:[26,29,40,94-96,98- \\
116,118]\end{array}$ \\
\hline & & or no effect & no effect: [97] \\
\hline & $\mathrm{TNF} \alpha$ & $\downarrow$ & $\downarrow:[26,40,101,105]$ \\
\hline & & or $\uparrow$ & $\uparrow:[117]$ \\
\hline & & or no effect & $\begin{array}{l}\text { no effect: }[94,95,97,109 \\
112,115,116,118]\end{array}$ \\
\hline & IL-6 & $\downarrow$ & $\downarrow:[26,94,97,98,100-$ \\
\hline & & or no effect & $\begin{array}{l}103,107,110- \\
113,115,116]\end{array}$ \\
\hline & & & no effect: $[95,96,109]$ \\
\hline & IL-7 & $\downarrow$ & {$[111]$} \\
\hline & IL-8 & $\downarrow$ & {$[113]$} \\
\hline & IL-18 & $\downarrow$ & {$[100-102,106,111]$} \\
\hline & sICAM-1 & $\downarrow$ & {$[26,104]$} \\
\hline & sVCAM-1 & $\downarrow$ & {$[26]$} \\
\hline
\end{tabular}


Table 1: Continued.

\begin{tabular}{|c|c|c|c|}
\hline Intervention & Marker of inflammation & Effect & Reference \\
\hline \multirow{5}{*}{ Orlistat } & hsCRP & $\downarrow$ & $\downarrow:[123-125,128]$ \\
\hline & & or no effect & no effect: $[126,127,133]$ \\
\hline & $\mathrm{TNF} \alpha$ & $\downarrow$ & {$[123,127,129]$} \\
\hline & IL-6 & $\downarrow$ & $\downarrow:[123,124,129]$ \\
\hline & & or no effect & no effect: [127] \\
\hline \multirow{5}{*}{ Sibutramine } & hsCRP & $\downarrow$ & $\downarrow:[132,133,147]$ \\
\hline & & or no effect & no effect: [135] \\
\hline & $\mathrm{TNF} \alpha$ & $\downarrow$ & {$[134]$} \\
\hline & IL-6 & $\downarrow$ & {$[134]$} \\
\hline & IL-10 & $\uparrow$ & {$[134]$} \\
\hline \multirow{10}{*}{ Metformin } & hsCRP & $\downarrow$ & $\downarrow:[139,141,144,146,147]$ \\
\hline & & or no effect & no effect: $[140,142,145]$ \\
\hline & $\mathrm{TNF} \alpha$ & No effect & {$[139,145]$} \\
\hline & IL-6 & $\downarrow$ & $\downarrow:[144]$ \\
\hline & & or no effect & no effect: $[139,145]$ \\
\hline & sICAM-1 & $\downarrow$ & $\downarrow:[139]$ \\
\hline & & or no effect & no effect: $[138,140,146]$ \\
\hline & sVCAM-1 & $\downarrow$ & {$[138-140,146]$} \\
\hline & soluble E-selectin & $\downarrow$ & $\downarrow:[139,140]$ \\
\hline & & or no effect & no effect: $[138,146]$ \\
\hline \multirow{10}{*}{ Roux-en-Y gastric bypass } & hsCRP & $\downarrow$ & {$[158-166]$} \\
\hline & $\mathrm{TNF} \alpha$ & No effect & {$[166]$} \\
\hline & sTNFR-2 & No effect & {$[166]$} \\
\hline & IL-6 & $\downarrow$ & $\downarrow:[160,162,163,165]$ \\
\hline & & or no effect & no effect: $[166]$ \\
\hline & IL-18 & $\downarrow$ & {$[180]$} \\
\hline & sICAM-1 & No effect & {$[166]$} \\
\hline & sVCAM-1 & No effect & {$[166]$} \\
\hline & soluble E-selectin & $\downarrow$ & {$[166]$} \\
\hline & MCP-1 & $\downarrow$ & {$[180]$} \\
\hline \multirow{13}{*}{ Gastric banding } & hsCRP & $\downarrow$ & $\downarrow:[158,169-175]$ \\
\hline & & or no effect & no effect: [176] \\
\hline & $\mathrm{TNF} \alpha$ & No effect & {$[172,174]$} \\
\hline & sTNFR-2 & $\downarrow$ & {$[167,180]$} \\
\hline & IL-6 & $\downarrow$ & $\downarrow:[171,172]$ \\
\hline & & or no effect & no effect: [174] \\
\hline & IL-18 & $\downarrow$ & {$[167]$} \\
\hline & sICAM-1 & $\downarrow$ & $\downarrow:[37,171,182]$ \\
\hline & & or no effect & no effect: [176] \\
\hline & sVCAM-1 & $\downarrow$ & $\downarrow:[176]$ \\
\hline & & or no effect & no effect: [181] \\
\hline & soluble E-selectin & $\downarrow$ & {$[37,176,181,182]$} \\
\hline & MCP-1 & $\downarrow$ & {$[167]$} \\
\hline \multirow{7}{*}{ Liposuction } & hsCRP & No effect & No effect: $[183,184]$ \\
\hline & & or $\downarrow$ & $\downarrow:[185]$ \\
\hline & $\mathrm{TNF} \alpha$ & No effect & No effect: $[183,184]$ \\
\hline & & or $\downarrow$ & $\downarrow:[185]$ \\
\hline & IL-6 & No effect & No effect: $[183,184]$ \\
\hline & & or $\downarrow$ & $\downarrow:[185]$ \\
\hline & IL-18 & $\downarrow$ & {$[185]$} \\
\hline
\end{tabular}


reduction of adipose tissue mass by $9 \pm 11 \%$ (or $2.5 \pm$ $3.0 \mathrm{~kg}$ ), exercise training did not affect hsCRP, IL-6, or TF $\alpha$ levels to a significant degree [92].

Differences in the type, frequency, intensity, and duration of exercise, in the amount of achieved weight loss, and/or in the duration of the study may partly explain the observed discrepancies in the effects of exercise on markers of inflammation. Moreover, the participants were mainly overweight or mildly obese, with variable baseline characteristics (age, gender, previous physical activity, all of which might have influenced the results). Finally, it has been reported that both strenuous exercise (which can lead to muscle damage) and overtraining (which might induce oxidative stress) might act as an inflammatory stimulus and raise inflammatory markers [86].

2.3. Combination of Diet and Exercise. More data are available on the effects of combining both diet and exercise on inflammatory markers (Table 1) [26, 29, 40, 94-114]. All studies ( $n=12-190$, duration 4 weeks to 2 years) reported a significant decrease in BMI in overweight [94, $111,112]$, obese $[26,29,40,95-107,109,111,112]$ and morbidly obese patients $[110,113,114]$. Interestingly, hsCRP levels significantly decreased in all but 1 of these studies $[26,29,40,94-96,98-114]$; the remaining study reported a nonsignificant fall in hsCRP concentration $(P=.71)$ [97]. In accordance with diet-only studies, hsCRP reductions after diet and exercise correlated positively with changes in body weight and fat mass [101]. The majority of studies also showed a significant decrease in serum IL-6 concentration after a multidisciplinary program including diet and exercise $[26,94,97,98,100-103,107,110-113]$ and only few studies did not $[95,96,109]$. Furthermore, all studies that evaluated the effects of caloric restriction and exercise on serum IL-18 levels observed a significant decrease [100-102, 106, 111]. Limited data also suggest that diet and increased physical activity decrease IL-7 [111], IL-8 [113], sICAM-1 [26, 104], and sVCAM-1 levels [26]. In contrast, the effects of diet and exercise on serum TNF $\alpha$ levels were less consistent with both significant decreases $[26,40,101,105]$ and no change reported [94, 95, 97, 109, 112].

Finally, 4 studies assessed the separate and combined effects of exercise and diet intervention on several cytokines. Nicklas et al. reported that an 18-month dietary intervention resulted in significant reductions in hsCRP and IL-6 concentrations (but not in TNF $\alpha$ levels) whereas exercise training had no effect; however, weight loss was observed only in patients on diet [115]. Patients on both diet and exercise did not show greater reductions in hsCRP and IL-6 levels than those on diet alone [115]. In another study, 6 months of diet plus exercise, but not exercise alone, decreased hsCRP and IL-6 levels (but not TNF $\alpha$ levels) in obese postmenopausal women despite a similar weight and fat loss in both groups [116]. Rokling-Andersen et al. randomly allocated 188 men with vascular risk factors to 4 groups: diet, exercise, combined diet and exercise, and control [117]. Serum TNF $\alpha$ levels increased significantly in the 3 intervention groups but the increase was smaller in the combined diet and exercise group and probably represents a chance finding [117]. In another study, 33 obese postmenopausal women with T2DM were assigned to diet, exercise, or diet and exercise for 14 weeks. Serum hsCRP levels decreased by approximately $15 \%$ with all interventions even though weight loss was observed only in patients assigned to diet alone or with exercise [118]. In contrast, serum TNF $\alpha$ levels did not change significantly [118].

The conflicting effects of the combination of diet and exercise on inflammatory markers are probably due to the short duration of the majority of the studies, the small number of participants, or the varying weight loss achieved. The lack of a decrease in serum TNF $\alpha$ concentration may be a result of its transient production and short half-life. Similar to the studies that assessed dietary modifications alone, a weight loss of at least $10 \%$ resulted in the greatest improvements in serological markers of inflammation in studies where diet was combined with exercise.

Overall, diet and exercise alone or in combination have favourable effects on serum inflammatory markers. The inconsistent findings in some studies may be due to (apart from the reasons already mentioned) differences in the studied population (i.e., overweight, obese, patients with diabetes), in the baseline concentration of cytokines and inflammatory status of each patient, as well as in the laboratory methods used for the measurement of cytokines.

\section{Antiobesity Agents}

Orlistat induces weight loss by reducing intestinal fat absorption (by up to $30 \%$ ) by binding to pancreatic lipases and partially inhibiting the hydrolysis of dietary fat (triglycerides) into absorbable free fatty acids and monoacylglycerols [119]. Compared with placebo, orlistat reduces body weight by approximately $2.9 \mathrm{~kg}$ (95\% confidence interval (CI) $2.5-$ $3.2 \mathrm{~kg}$ ) in studies lasting more than 1 year [120]. In addition, orlistat lowers low density lipoprotein cholesterol (LDL-C) levels, reduces blood pressure (BP), and improves glycemic control in diabetic patients $[120,121]$. More importantly, in XENical in the prevention of Diabetes in Obese Subjects (XENDOS) study, orlistat reduced the risk of developing T2DM in obese patients with impaired glucose tolerance [122].

A limited number of studies evaluated the effects of orlistat on inflammatory markers in obese patients (Table 1). In some reports, treatment with orlistat for up to 1 year reduced hsCRP levels [123-125]. However, in other studies the fall in CRP levels during orlistat treatment did not reach statistical significance $[126,127]$. In addition, in a placebo-controlled study that evaluated the effects of longterm (3 years) treatment with orlistat, hsCRP levels decreased significantly only in patients who lost more than $11 \%$ of their body weight [128]. It is of interest to point out that all 3 studies that reported a decrease in hsCRP levels during orlistat treatment [123-125] lasted for 6 months or more and hsCRP levels were measured. In contrast, negative studies evaluated CRP levels, which are less sensitive for evaluating inflammation than hsCRP $[126,127]$. Moreover, baseline 
CRP levels were within the normal range in both negative studies and this might have limited their statistical power to show a significant decrease in CRP levels [126, 127]. Finally, both negative studies had shorter follow-up than the studies that reported a decrease in hsCRP levels during orlistat treatment ( 3 and 4 months, resp.) and the potential antiinflammatory effect of orlistat might have not become apparent yet at study completion [123-127].

A reduction in serum IL-6 $[123,124,129]$ and TNF $\alpha$ levels was also reported after treatment with orlistat [123, $127,129]$. Orlistat did not affect serum IL-6 levels only in one study, which however had a short follow-up as already mentioned (4 months versus 6 months or more in other reports) [127]. Interestingly, the decrease in hsCRP and TNF $\alpha$ in some studies was greater in the diet plus orlistat group compared with patients who were only on diet even after correcting for the greater weight loss observed in the orlistat group $[123,125,129]$. Overall, it appears that 6 months or more of treatment with orlistat and a weight loss greater than $10 \%$ are required for a significant reduction in inflammatory markers with this agent.

Sibutramine lowers body weight by increasing satiety and by reducing appetite through the selective inhibition of the neuronal reuptake of serotonin and noradrenaline within the hypothalamus $[130,131]$. In studies lasting more than 1 year, sibutramine reduced body weight by approximately $4.2 \mathrm{~kg}$ (95\% CI 3.6-4.7 kg) compared with placebo [120, 130]. Sibutramine also lowers triglyceride (TG) levels but increases $\mathrm{BP}$ and pulse rate $[120,130]$.

In some studies, sibutramine reduced serum levels of hsCRP [132, 133], IL-6, and TNF $\alpha$ and increased serum levels of IL-10 when given for 3-6 months (Table 1) [134]. A weight loss of $6.1-7.1 \mathrm{~kg}(5.4 \%-6.9 \%)$ was observed during the latter studies $[133,134]$ and correlated with the reduction in IL-6 levels [134]. In another study, treatment with sibutramine for 6 months did not affect hsCRP levels; however, the weight loss achieved in this study was substantially smaller $(2.4 \mathrm{~kg}$ or $2.9 \%)$ [135]. Therefore, similarly with orlistat, weight loss appears to be the major factor that determines the anti-inflammatory effect of sibutramine.

In a nonrandomized, nonblinded comparative study, only sibutramine reduced hsCRP levels after 6 months whereas changes in hsCRP levels were nonsignificant in patients given orlistat [133]. However, weight loss was greater in the sibutramine group compared with the orlistat group ( $5.4 \%$ versus $2.5 \%$, resp.), suggesting again that the degree of weight loss correlates with the anti-inflammatory action of these antiobesity agents [133]. Whether orlistat or sibutramine exerts an anti-inflammatory action independently of weight loss is unclear.

It should emphasized that the Committee for Medicinal Products for Human Use of the European Medicines Agency recently concluded that the risks of sibutramine are greater than its benefits and recommended the suspension of marketing authorization of this agent across the European Union (http://www.ema.europa.eu/pdfs/human/ referral/sibutramine/3940810en.pdf; accessed 25/1/2010). The Food and Drug Administration also stated that sibutramine is not to be used in patients with a history of coronary heart disease, stroke or transient ischemic attack, heart failure, heart arrhythmias, peripheral arterial disease, or uncontrolled hypertension (http://www.fda.gov/Safety/ MedWatch/SafetyInformation/SafetyAlertsforHumanMedicalProducts/ucm 198221.htm; accessed 25/1/2010). These recommendations were based on the results of the Sibutramine Cardiovascular Outcome Trial (SCOUT), which showed an increased risk of nonfatal cardiovascular events with sibutramine compared with placebo in patients with known or high risk for cardiovascular disease (http://www .ema.europa.eu/pdfs/human/referral/sibutramine/3940810en.pdf and http://www.fda.gov/Safety/MedWatch/SafetyInformation/SafetyAlertsforHumanMedicalProducts/ucm198221.htm; accessed 25/1/2010).

Metformin enhances insulin sensitivity, lowers hepatic glucose production, and is a first-line treatment for T2DM $[136,137]$. Metformin frequently induces a modest weight loss in diabetic patients [136]. In 4 studies in patients with T2DM, treatment with metformin for 3-4 months exerted conflicting effects on serum hsCRP, IL-6, TNF $\alpha$, sICAM-1, sVCAM-1, and soluble E-selectin levels (Table 1) [138-141]. In one study where metformin was administered only for 1 month, no significant change was observed in hsCRP levels [142]. Metformin is also used in the management of patients with polycystic ovary syndrome (PCOS), where it has been shown to ameliorate reproductive abnormalities, restore ovulation and regular menses, increase pregnancy rates, and reduce androgen production [143]. In 3 studies in women with PCOS, treatment with metformin for 6 months also had contradictory effects on hsCRP, IL-6, TNF- $\alpha$, sICAM-1, sVCAM-1, and soluble E-selectin levels (Table 1) [144-146]. In addition to the unclear effects of metformin on inflammatory markers, it should be emphasized that metformin is not currently recommended for the management of obesity. Moreover, a recent study in nondiabetic obese women showed that sibutramine monotherapy reduced hsCRP levels and that adding metformin to sibutramine did not result in any additional decrease in hsCRP levels [147].

\section{Bariatric Surgery}

Bariatric surgery is classified in restrictive (laparoscopic adjustable gastric banding and vertical banded gastroplasty), malabsorptive (biliopancreatic diversion with or without duodenal switch), and combination procedures (Roux-en-Y gastric bypass) [148]. All forms of bariatric surgery result in loss of more than $50 \%$ of excess weight [149]. In addition, hypertension, T2DM, hyperlipidemia, and obstructive sleep apnea resolve in the majority of patients who undergo bariatric surgery [149]. More importantly, bariatric surgery was associated with reduced all-cause mortality in several retrospective studies [150-152] and in a prospective study [153]. Malabsorptive or combination procedures induce greater weight loss [152, 154-157] and appear to be more effective in the resolution of obesity-associated comorbidities $[149,157]$. However, they are also associated with higher complication rates compared with restrictive procedures $[149,151,154]$. 
Several studies reported a reduction in serum hsCRP levels after Roux-en-Y gastric bypass (Table 1) [158-166]. This decrease in hsCRP levels is greater in patients who lost more weight after surgery $[164,166]$. A decline in hsCRP levels also occurs in patients undergoing gastric banding (Table 1) [158, 167-175]. The decrease in hsCRP levels correlated with the fall in BMI in some of these studies [172]. Only one study did not report a significant change of hsCRP levels after gastric banding; however, the decrease in hsCRP levels in this report was significant 6 months after surgery $(P=.05)$ and there was a trend for significant decrease also at 12 months $(P=.08)$ [176]. In a recent study, patients who underwent gastric bypass lost more weight than those who underwent gastric banding but the fall in hsCRP levels was similar in both groups [158]. Other less frequently performed bariatric procedures, such as biliopancreatic diversion [177], laparoscopic sleeve gastrectomy [178], and gastric partition [179], also result in a decrease in hsCRP levels that in some cases correlates with the reduction in BMI [178]. The reduction in hsCRP levels in almost all studies of all types of bariatric surgery, in contradiction to the equivocal results of lifestyle changes and antiobesity agents, further supports the notion that weight loss per se is the main factor that causes the fall in hsCRP levels, since bariatric surgery results in substantially greater weight loss than lifestyle changes or antiobesity agents. The lack of correlation between weight loss and hsCRP fall might be attributed to the small number of patients included in these studies, which limits their statistical power.

Other markers of inflammation, including IL-6 [160, 162, 163, 165], IL-18 [180], MCP-1 [180], and soluble Eselectin [166] also fall after gastric bypass (Table 1). Only 1 small study $(n=26)$ did not report significant changes in IL-6, TNF $\alpha$, sTNFR-2, sICAM-1, and sVCAM-1 levels following gastric bypass [166]. However, serum hsCRP levels, which are a more sensitive and specific marker of inflammation, decreased in this study [166]. Serum levels of IL-6 [171, 172], IL-18 [167], sTNFR-2 [167, 170], MCP1 [167], soluble E-selectin [37, 176, 181, 182], sICAM-1 [37, 181, 182], and sVCAM-1 levels [176] also fall after gastric banding (Table 1). The change in soluble E-selectin and sICAM-1 levels correlated with the reduction in BMI [37, 182]. However, IL-6 [174], sVCAM-1 [181], and sICAM1 levels [176] did not change significantly in other studies. In addition, serum TNF $\alpha$ levels $[172,174]$ were not affected by gastric banding. Again, serum hsCRP levels fell in most studies that did not record a significant change in other inflammatory markers $[172,174]$, suggesting that the latter might be less sensitive in identifying a clinically significant anti-inflammatory effect of bariatric surgery.

In contrast to bariatric surgery, removal of abdominal subcutaneous fat by liposuction does not appear to reduce hsCRP, IL-6, or TNF $\alpha$ levels (Table 1) [183, 184]. However, one study reported a reduction in serum hsCRP, IL-6, IL-18, and TNF $\alpha$ levels after liposuction [185]. In the latter study, the amount of fat aspirate correlated with the reduction in TNF $\alpha$ levels [185]. Even though the data on the effect of liposuction on inflammatory markers are limited, the predominantly negative findings are concordant with the concept that visceral adipose tissue is the main factor inducing the inflammatory milieu of obese patients whereas subcutaneous adipose tissue is less important.

\section{Conclusions}

Existing evidence suggests that lifestyle measures, antiobesity agents, and bariatric surgery reduce serum levels of inflammatory markers in obese patients. The lack of significant change in some studies appears to be due to small sample size and/or small weight loss achieved. It appears that the reduction in inflammation is primarily driven by weight loss [186]. In a recent meta-analysis, a linear relation was observed between weight loss following lifestyle changes or bariatric surgery and the fall in hsCRP levels, which declined by $0.13 \mathrm{mg} / \mathrm{L}$ for each $1 \mathrm{~kg}$ of weight loss [186]. What remains to be established is whether reducing inflammatory markers in obese patients with lifestyle measures or (where indicated) with bariatric surgery or drugs will translate in lower vascular risk. In this context, a beneficial effect of suppressing inflammation has been reported during statin treatment in patients with or without established vascular disease, even though it was not assessed whether obese patients benefit more or less [187-189].

\section{References}

[1] C. L. Ogden, M. D. Carroll, L. R. Curtin, M. A. McDowell, C. J. Tabak, and K. M. Flegal, "Prevalence of overweight and obesity in the United States, 1999-2004," Journal of the American Medical Association, vol. 295, no. 13, pp. 15491555, 2006.

[2] W. P. T. James, "The epidemiology of obesity: the size of the problem," Journal of Internal Medicine, vol. 263, no. 4, pp. 336-352, 2008.

[3] T. Pischon, H. Boeing, K. Hoffmann, et al., "General and abdominal adiposity and risk of death in Europe," The New England Journal of Medicine, vol. 359, no. 20, pp. 2105-2120, 2008.

[4] K. F. Adams, A. Schatzkin, T. B. Harris, et al., "Overweight, obesity, and mortality in a large prospective cohort of persons 50 to 71 years old," The New England Journal of Medicine, vol. 355, no. 8, pp. 763-778, 2006.

[5] F. B. Hu, W. C. Willett, T. Li, M. J. Stampfer, G. A. Colditz, and J. E. Manson, "Adiposity as compared with physical activity in predicting mortality among women," The New England Journal of Medicine, vol. 351, no. 26, pp. 2694-2703, 2004.

[6] L. Fontana, J. C. Eagon, M. E. Trujillo, P. E. Scherer, and S. Klein, "Visceral fat adipokine secretion is associated with systemic inflammation in obese humans," Diabetes, vol. 56, no. 4, pp. 1010-1013, 2007.

[7] J. N. Fain, A. K. Madan, M. L. Hiler, P. Cheema, and S. W. Bahouth, "Comparison of the release of adipokines by adipose tissue, adipose tissue matrix, and adipocytes from visceral and subcutaneous abdominal adipose tissues of obese humans," Endocrinology, vol. 145, no. 5, pp. 22732282,2004

[8] S. K. Fried, D. A. Bunkin, and A. S. Greenberg, "Omental and subcutaneous adipose tissues of obese subjects release 
interleukin-6: depot difference and regulation by glucocorticoid," Journal of Clinical Endocrinology and Metabolism, vol. 83, no. 3, pp. 847-850, 1998.

[9] V. Mohamed-Ali, S. Goodrick, A. Rawesh, et al., "Subcutaneous adipose tissue releases interleukin- 6 , but not tumor necrosis factor- $\alpha$, in vivo," Journal of Clinical Endocrinology and Metabolism, vol. 82, no. 12, pp. 4196-4200, 1997.

[10] G. S. Hotamisligil, P. Arner, J. F. Caro, R. L. Atkinson, and B. M. Spiegelman, "Increased adipose tissue expression of tumor necrosis factor- $\alpha$ in human obesity and insulin resistance," Journal of Clinical Investigation, vol. 95, no. 5, pp. 2409-2415, 1995.

[11] P. A. Kern, M. Saghizadeh, J. M. Ong, R. J. Bosch, R. Deem, and R. B. Simsolo, "The expression of tumor necrosis factor in human adipose tissue. Regulation by obesity, weight loss, and relationship to lipoprotein lipase," Journal of Clinical Investigation, vol. 95, no. 5, pp. 2111-2119, 1995.

[12] J. M. Bruun, A. S. Lihn, S. B. Pedersen, and B. Richelsen, "Monocyte chemoattractant protein-1 release is higher in visceral than subcutaneous human adipose tissue (AT): implication of macrophages resident in the AT," Journal of Clinical Endocrinology and Metabolism, vol. 90, no. 4, pp. 2282-2289, 2005.

[13] T. Christiansen, B. Richelsen, and J. M. Bruun, "Monocyte chemoattractant protein-1 is produced in isolated adipocytes, associated with adiposity and reduced after weight loss in morbid obese subjects," International Journal of Obesity, vol. 29, no. 1, pp. 146-150, 2005.

[14] M. Miller, M. Zhan, and S. Havas, "High attributable risk of elevated C-reactive protein level to conventional coronary heart disease risk factors: the Third National Health and Nutrition Examination Survey," Archives of Internal Medicine, vol. 165, no. 18, pp. 2063-2068, 2005.

[15] M. Visser, L. M. Bouter, G. M. McQuillan, M. H. Wener, and T. B. Harris, "Elevated C-reactive protein levels in overweight and obese adults," Journal of the American Medical Association, vol. 282, no. 22, pp. 2131-2135, 1999.

[16] E. S. Ford, "Body mass index, diabetes, and C-reactive protein among U.S. adults," Diabetes Care, vol. 22, no. 12, pp. 1971-1977, 1999.

[17] A. E. Hak, C. D. A. Stehouwer, M. L. Bots, et al., "Associations of C-reactive protein with measures of obesity, insulin resistance, and subclinical atherosclerosis in healthy, middle-aged women," Arteriosclerosis, Thrombosis, and Vascular Biology, vol. 19, no. 8, pp. 1986-1991, 1999.

[18] S. Mora, I.-M. Lee, J. E. Buring, and P. M. Ridker, "Association of physical activity and body mass index with novel and traditional cardiovascular biomarkers in women," Journal of the American Medical Association, vol. 295, no. 12, pp. 14121419, 2006.

[19] E. A. Bermudez, N. Rifai, J. Buring, J. E. Manson, and P. M. Ridker, "Interrelationships among circulating interleukin-6, C-reactive protein, and traditional cardiovascular risk factors in women," Arteriosclerosis, Thrombosis, and Vascular Biology, vol. 22, no. 10, pp. 1668-1673, 2002.

[20] A. Tchernof, A. Nolan, C. K. Sites, P. A. Ades, and E. T. Poehlman, "Weight loss reduces C-reactive protein levels in obese postmenopausal women," Circulation, vol. 105, no. 5, pp. 564-569, 2002.

[21] A. Festa, R. D’Agostino Jr., K. Williams, et al., “The relation of body fat mass and distribution to markers of chronic inflammation," International Journal of Obesity, vol. 25, no. 10, pp. 1407-1415, 2001.
[22] L. K. Heilbronn, M. Noakes, and P. M. Clifton, "Energy restriction and weight loss on very-low-fat diets reduce Creactive protein concentrations in obese, healthy women," Arteriosclerosis, Thrombosis, and Vascular Biology, vol. 21, no. 6, pp. 968-970, 2001.

[23] A. Festa, R. D’Agostino Jr., G. Howard, L. Mykkänen, R. P. Tracy, and S. M. Haffner, "Chronic subclinical inflammation as part of the insulin resistance syndrome: the insulin resistance atherosclerosis study (IRAS)," Circulation, vol. 102, no. 1, pp. 42-47, 2000.

[24] J. S. Yudkin, C. D. A. Stehouwer, J. J. Emeis, and S. W. Coppack, "C-reactive protein in healthy subjects: associations with obesity, insulin resistance, and endothelial dysfunction: a potential role for cytokines originating from adipose tissue?" Arteriosclerosis, Thrombosis, and Vascular Biology, vol. 19, no. 4, pp. 972-978, 1999.

[25] R. P. Tracy, B. M. Psaty, E. Macy, et al., "Lifetime smoking exposure affects the association of C-reactive protein with cardiovascular disease risk factors and subclinical disease in healthy elderly subjects," Arteriosclerosis, Thrombosis, and Vascular Biology, vol. 17, no. 10, pp. 2167-2176, 1997.

[26] P. Ziccardi, F. Nappo, G. Giugliano, et al., "Reduction of inflammatory cytokine concentrations and improvement of endothelial functions in obese women after weight loss over one year," Circulation, vol. 105, no. 7, pp. 804-809, 2002.

[27] K. M. Pou, J. M. Massaro, U. Hoffmann, et al., "Visceral and subcutaneous adipose tissue volumes are cross-sectionally related to markers of inflammation and oxidative stress: the Framingham Heart Study," Circulation, vol. 116, no. 11, pp. 1234-1241, 2007.

[28] J.-P. Bastard, C. Jardel, E. Bruckert, et al., "Elevated levels of interleukin 6 are reduced in serum and subcutaneous adipose tissue of obese women after weight loss," Journal of Clinical Endocrinology and Metabolism, vol. 85, no. 9, pp. 3338-3342, 2000.

[29] P. Dandona, R. Weinstock, K. Thusu, E. Abdel-Rahman, A. Aljada, and T. Wadden, "Tumor necrosis factor- $\alpha$ in sera of obese patients: fall with weight loss," Journal of Clinical Endocrinology and Metabolism, vol. 83, no. 8, pp. 2907-2910, 1998.

[30] M. A. Mendall, P. Patel, M. Asante, et al., "Relation of serum cytokine concentrations to cardiovascular risk factors and coronary heart disease," Heart, vol. 78, no. 3, pp. 273-277, 1997.

[31] J. M. Bruun, C. Verdich, S. Toubro, A. Astrup, and B. Richelsen, "Association between measures of insulin sensitivity and circulating levels of interleukin-8, interleukin- 6 and tumor necrosis factor- $\alpha$. Effect of weight loss in obese men," European Journal of Endocrinology, vol. 148, no. 5, pp. 535542, 2003.

[32] M. Straczkowski, S. Dzienis-Straczkowska, A. Stepien, I. Kowalska, M. Szelachowska, and I. Kinalska, "Plasma interleukin- 8 concentrations are increased in obese subjects and related to fat mass and tumor necrosis factor- $\alpha$ system," Journal of Clinical Endocrinology and Metabolism, vol. 87, no. 10, pp. 4602-4606, 2002.

[33] K. Esposito, A. Pontillo, M. Ciotola, et al., "Weight loss reduces interleukin-18 levels in obese women," Journal of Clinical Endocrinology and Metabolism, vol. 87, no. 8, pp. 3864-3866, 2002.

[34] M. Straczkowski, P. Lewczuk, S. Dzienis-Straczkowska, I. Kowalska, A. Stepien, and I. Kinalska, "Elevated soluble intercellular adhesion molecule-1 levels in obesity: relationship 
to insulin resistance and tumor necrosis factor- $\alpha$ system activity," Metabolism, vol. 51, no. 1, pp. 75-78, 2002.

[35] M. Straczkowski, I. Kowalska, S. Dzienis-Straczkowska, et al., "Changes in tumor necrosis factor- $\alpha$ system and insulin sensitivity during an exercise training program in obese women with normal and impaired flucose tolerance," European Journal of Endocrinology, vol. 145, no. 3, pp. 273-280, 2001.

[36] C. Ferri, G. Desideri, M. Valenti, et al., "Early upregulation of endothelial adhesion molecules in obese hypertensive men," Hypertension, vol. 34, no. 4, pp. 568-573, 1999.

[37] A. E. Pontiroli, P. Pizzocri, D. Koprivec, et al., "Body weight and glucose metabolism have a different effect on circulating levels of ICAM-1, E-selectin, and endothelin-1 in humans," European Journal of Endocrinology, vol. 150, no. 2, pp. 195200, 2004.

[38] J. F. Keaney Jr., J. M. Massaro, M. G. Larson, et al., "Heritability and correlates of intercellular adhesion molecule- 1 in the Framingham Offspring Study," Journal of the American College of Cardiology, vol. 44, no. 1, pp. 168-173, 2004.

[39] I. Lemieux, A. Pascot, D. Prud'homme, et al., "Elevated Creactive protein: another component of the atherothrombotic profile of abdominal obesity," Arteriosclerosis, Thrombosis, and Vascular Biology, vol. 21, no. 6, pp. 961-967, 2001.

[40] A. Katsuki, Y. Sumida, S. Murashima, et al., "Serum levels of tumor necrosis factor- $\alpha$ are increased in obese patients with noninsulin-dependent diabetes mellitus," Journal of Clinical Endocrinology and Metabolism, vol. 83, no. 3, pp. 859-862, 1998.

[41] C. Couillard, G. Ruel, W. R. Archer, et al., "Circulating levels of oxidative stress markers and endothelial adhesion molecules in men with abdominal obesity," Journal of Clinical Endocrinology and Metabolism, vol. 90, no. 12, pp. 6454 6459, 2005.

[42] J. A. de Lemos, D. A. Morrow, M. S. Sabatine, et al., "Association between plasma levels of monocyte chemoattractant protein-1 and long-term clinical outcomes in patients with acute coronary syndromes," Circulation, vol. 107, no. 5, pp. 690-695, 2003.

[43] A. D. Pradhan, J. E. Manson, J. E. Rossouw, et al., "Inflammatory biomarkers, hormone replacement therapy, and incident coronary heart disease: prospective analysis from the women's health initiative observational study," Journal of the American Medical Association, vol. 288, no. 8, pp. 980-987, 2002.

[44] P. M. Ridker, N. Rifai, M. Pfeffer, F. Sacks, S. Lepage, and E. Braunwald, "Elevation of tumor necrosis factor- $\alpha$ and increased risk of recurrent coronary events after myocardial infarction," Circulation, vol. 101, no. 18, pp. 2149-2153, 2000.

[45] P. M. Ridker, N. Rifai, M. J. Stampfer, and C. H. Hennekens, "Plasma concentration of interleukin-6 and the risk of future myocardial infarction among apparently healthy men," Circulation, vol. 101, no. 15, pp. 1767-1772, 2000.

[46] D. I. Buckley, R. Fu, M. Freeman, K. Rogers, and M. Helfand, "C-reactive protein as a risk factor for coronary heart disease: a systematic review and meta-analyses for the U.S. Preventive Services Task Force," Annals of Internal Medicine, vol. 151, no. 7, pp. 483-495, 2009.

[47] V. Snow, P. Barry, N. Fitterman, et al., "Pharmacologic and surgical management of obesity in primary care: a clinical practice guideline from the American College of Physicians," Annals of Internal Medicine, vol. 142, no. 7, pp. 525-531, 2005.
[48] J. Tuomilehto, J. Lindstrom, J. G. Eriksson, et al., "Prevention of type 2 diabetes mellitus by changes in lifestyle among subjects with impaired glucose tolerance," The New England Journal of Medicine, vol. 344, no. 18, pp. 1343-1350, 2001.

[49] W. C. Knowler, E. Barrett-Connor, S. E. Fowler, et al., "Reduction in the incidence of type 2 diabetes with lifestyle intervention or metformin," The New England Journal of Medicine, vol. 346, no. 6, pp. 393-403, 2002.

[50] S. Eilat-Adar, M. Eldar, and U. Goldbourt, "Association of intentional changes in body weight with coronary heart disease event rates in overweight subjects who have an additional coronary risk factor," American Journal of Epidemiology, vol. 161, no. 4, pp. 352-358, 2005.

[51] E. W. Gregg, R. B. Gerzoff, T. J. Thompson, and D. F. Williamson, "Intentional weight loss and death in overweight and obese U.S. adults 35 years of age and older," Annals of Internal Medicine, vol. 138, no. 5, pp. 383-389, 2003.

[52] G. D. Brinkworth, M. Noakes, J. B. Keogh, N. D. Luscombe, G. A. Wittert, and P. M. Clifton, "Long-term effects of a high-protein, low-carbohydrate diet on weight control and cardiovascular risk markers in obese hyperinsulinemic subjects," International Journal of Obesity, vol. 28, no. 5, pp. 661-670, 2004.

[53] G. D. Brinkworth, M. Noakes, B. Parker, P. Foster, and P. M. Clifton, "Long-term effects of advice to consume a highprotein, low-fat diet, rather than a conventional weight-loss diet, in obese adults with type 2 diabetes: one-year followup of a randomised trial," Diabetologia, vol. 47, no. 10, pp. 1677-1686, 2004.

[54] G. D. Brinkworth, M. Noakes, J. D. Buckley, J. B. Keogh, and P. M. Clifton, "Long-term effects of a very-low-carbohydrate weight loss diet compared with an isocaloric low-fat diet after 12 mo," American Journal of Clinical Nutrition, vol. 90, no. 1, pp. 23-32, 2009.

[55] P. M. Clifton, J. B. Keogh, P. R. Foster, and M. Noakes, "Effect of weight loss on inflammatory and endothelial markers and FMD using two low-fat diets," International Journal of Obesity, vol. 29, no. 12, pp. 1445-1451, 2005.

[56] M. L. Dansinger, J. A. Gleason, J. L. Griffith, H. P. Selker, and E. J. Schaefer, "Comparison of the Atkins, Ornish, Weight Watchers, and Zone Diets for weight loss and heart disease risk reduction: a randomized trial," Journal of the American Medical Association, vol. 293, no. 1, pp. 43-53, 2005.

[57] A. Due, S. Toubro, S. Stender, A. R. Skov, and A. Astrup, "The effect of diets high in protein or carbohydrate on inflammatory markers in overweight subjects," Diabetes, Obesity and Metabolism, vol. 7, no. 3, pp. 223-229, 2005.

[58] S. M. Hannum, L. Carson, E. M. Evans, et al., "Use of portion-controlled entrees enhances weight loss in women," Obesity Research, vol. 12, no. 3, pp. 538-546, 2004.

[59] A. H. Heald, C. Golding, R. Sharma, et al., "A substitution model of dietary manipulation is an effective means of optimising lipid profile, reducing C-reactive protein and increasing insulin-like growth factor-1," British Journal of Nutrition, vol. 92, no. 5, pp. 809-818, 2004.

[60] S. E. Kasim-Karakas, A. Tsodikov, U. Singh, and I. Jialal, "Responses of inflammatory markers to a low-fat, highcarbohydrate diet: effects of energy intake," American Journal of Clinical Nutrition, vol. 83, no. 4, pp. 774-779, 2006.

[61] J. B. Keogh, G. D. Brinkworth, and P. M. Clifton, "Effects of weight loss on a low-carbohydrate diet on flow-mediated dilatation, adhesion molecules and adiponectin," British Journal of Nutrition, vol. 98, no. 4, pp. 852-859, 2007. 
[62] J. B. Keogh, G. D. Brinkworth, M. Noakes, D. P. Belobrajdic, J. D. Buckley, and P. M. Clifton, "Effects of weight loss from a very-low-carbohydrate diet on endothelial function and markers of cardiovascular disease risk in subjects with abdominal obesity," American Journal of Clinical Nutrition, vol. 87, no. 3, pp. 567-576, 2008.

[63] G. Mazzali, V. Di Francesco, E. Zoico, et al., "Interrelations between fat distribution, muscle lipid content, adipocytokines, and insulin resistance: effect of moderate weight loss in older women," American Journal of Clinical Nutrition, vol. 84, no. 5, pp. 1193-1199, 2006.

[64] T. McLaughlin, F. Abbasi, C. Lamendola, et al., "Differentiation between obesity and insulin resistance in the association with C-reactive protein," Circulation, vol. 106, no. 23, pp. 2908-2912, 2002.

[65] M. Noakes, J. B. Keogh, P. R. Foster, and P. M. Clifton, "Effect of an energy-restricted, high-protein, low-fat diet relative to a conventional high-carbohydrate, low-fat diet on weight loss, body composition, nutritional status, and markers of cardiovascular health in obese women," American Journal of Clinical Nutrition, vol. 81, no. 6, pp. 1298-1306, 2005.

[66] M. Noakes, P. R. Foster, J. B. Keogh, A. P. James, J. C. Mamo, and P. M. Clifton, "Comparison of isocaloric very low carbohydrate/high saturated fat and high carbohydrate/low saturated fat diets on body composition and cardiovascular risk," Nutrition and Metabolism, vol. 3, article 7, 2006.

[67] K. D. O’Brien, B. J. Brehm, R. J. Seeley, et al., "Diet-induced weight loss is associated with decreases in plasma serum amyloid A and C-reactive protein independent of dietary macronutrient composition in obese subjects," Journal of Clinical Endocrinology and Metabolism, vol. 90, no. 4, pp. 2244-2249, 2005.

[68] M. A. Pereira, J. Swain, A. B. Goldfine, N. Rifai, and D. S. Ludwig, "Effects of a low-glycemic load diet on resting energy expenditure and heart disease risk factors during weight loss," Journal of the American Medical Association, vol. 292, no. 20, pp. 2482-2490, 2004.

[69] M. Raitakari, T. Ilvonen, M. Ahotupa, et al., "Weight reduction with very-low-caloric diet and endothelial function in overweight adults: role of plasma glucose," Arteriosclerosis, Thrombosis, and Vascular Biology, vol. 24, no. 1, pp. 124-128, 2004.

[70] J. C. Ratliff, G. Mutungi, M. J. Puglisi, J. S. Volek, and M. L. Fernandez, "Eggs modulate the inflammatory response to carbohydrate restricted diets in overweight men," Nutrition and Metabolism, vol. 5, no. 1, article 6, 2008.

[71] P. Seshadri, N. Iqbal, L. Stern, et al., "A randomized study comparing the effects of a low-carbohydrate diet and a conventional diet on lipoprotein subfractions and C-reactive protein levels in patients with severe obesity," American Journal of Medicine, vol. 117, no. 6, pp. 398-405, 2004.

[72] M. J. Sharman and J. S. Volek, "Weight loss leads to reductions in inflammatory biomarkers after a very-lowcarbohydrate diet and a low-fat diet in overweight men," Clinical Science, vol. 107, no. 4, pp. 365-369, 2004.

[73] J. Tay, G. D. Brinkworth, M. Noakes, J. Keogh, and P. M. Clifton, "Metabolic effects of weight loss on a verylow-carbohydrate diet compared with an isocaloric highcarbohydrate diet in abdominally obese subjects," Journal of the American College of Cardiology, vol. 51, no. 1, pp. 59-67, 2008.

[74] R. J. Wood, J. S. Volek, S. R. Davis, C. Dell'Ova, and M. L. Fernandez, "Effects of a carbohydrate-restricted diet on emerging plasma markers for cardiovascular disease," Nutrition and Metabolism, vol. 3, article 19, 2006.

[75] A. M. Xydakis, C. C. Case, P. H. Jones, et al., "Adiponectin, inflammation, and the expression of the metabolic syndrome in obese individuals: the impact of rapid weight lose through caloric restriction," Journal of Clinical Endocrinology and Metabolism, vol. 89, no. 6, pp. 2697-2703, 2004.

[76] E. Arvidsson, N. Viguerie, I. Andersson, C. Verdich, D. Langin, and P. Arner, "Effects of different hypocaloric diets on protein secretion from adipose tissue of obese women," Diabetes, vol. 53, no. 8, pp. 1966-1971, 2004.

[77] C. Xenachis, E. Samojlik, M. P. Raghuwanshi, and M. A. Kirschner, "Leptin, insulin and TNF- $\alpha$ in weight loss," Journal of Endocrinological Investigation, vol. 24, no. 11, pp. 865-870, 2001.

[78] M. R. Manigrasso, P. Ferroni, F. Santilli, et al., "Association between circulating adiponectin and interleukin-10 levels in android obesity: effects of weight loss," Journal of Clinical Endocrinology and Metabolism, vol. 90, no. 10, pp. 58765879, 2005.

[79] M. I. Maiorino, B. Schisano, C. Di Palo, et al., "Interleukin20 circulating levels in obese women: effect of weight loss," Nutrition, Metabolism and Cardiovascular Diseases. In press.

[80] E. Porreca, C. Di Febbo, L. Fusco, V. Moretta, M. Di Nisio, and F. Cuccurullo, "Soluble thrombomodulin and vascular adhesion molecule-1 are associated to leptin plasma levels in obese women," Atherosclerosis, vol. 172, no. 1, pp. 175-180, 2004.

[81] J. R. Mitchell, M. Verweij, K. Brand, et al., "Short-term dietary restriction and fasting precondition against ischemia reperfusion injury in mice," Aging Cell, vol. 9, pp. 40-53, 2010.

[82] A. Gugliucci, K. Kotani, J. Taing, et al., "Short-term low calorie diet intervention reduces serum advanced glycation end products in healthy overweight or obese adults," Annals of Nutrition and Metabolism, vol. 54, no. 3, pp. 197-201, 2009.

[83] P. T. Campbell, K. L. Campbell, M. H. Wener, et al., "A yearlong exercise intervention decreases CRP among obese postmenopausal women," Medicine and Science in Sports and Exercise, vol. 41, no. 8, pp. 1533-1539, 2009.

[84] N. P. E. Kadoglou, F. Iliadis, N. Angelopoulou, et al., "The anti-inflammatory effects of exercise training in patients with type 2 diabetes mellitus," European Journal of Cardiovascular Prevention and Rehabilitation, vol. 14, no. 6, pp. 837-843, 2007.

[85] T. P. Olson, D. R. Dengel, A. S. Leon, and K. H. Schmitz, "Changes in inflammatory biomarkers following one-year of moderate resistance training in overweight women," International Journal of Obesity, vol. 31, no. 6, pp. 996-1003, 2007.

[86] K. Okita, H. Nishijima, T. Murakami, et al., "Can exercise training with weight loss lower serum C-reactive protein levels?" Arteriosclerosis, Thrombosis, and Vascular Biology, vol. 24, no. 10, pp. 1868-1873, 2004.

[87] T. Kondo, I. Kobayashi, and M. Murakami, "Effect of exercise on circulating adipokine levels in obese young women," Endocrine Journal, vol. 53, no. 2, pp. 189-195, 2006.

[88] K. L. Campbell, P. T. Campbell, C. M. Ulrich, et al., "No reduction in C-reactive protein following a 12-month randomized controlled trial of exercise in men and women," Cancer Epidemiology Biomarkers and Prevention, vol. 17, no. 7, pp. 1714-1718, 2008. 
[89] M. C. Devries, M. J. Hamadeh, A. W. Glover, S. Raha, I. A. Samjoo, and M. A. Tarnopolsky, "Endurance training without weight loss lowers systemic, but not muscle, oxidative stress with no effect on inflammation in lean and obese women," Free Radical Biology and Medicine, vol. 45, no. 4, pp. 503-511, 2008.

[90] M. J. Dekker, S. Lee, R. Hudson, et al., "An exercise intervention without weight loss decreases circulating interleukin6 in lean and obese men with and without type 2 diabetes mellitus," Metabolism, vol. 56, no. 3, pp. 332-338, 2007.

[91] S. Tsukui, T. Kanda, M. Nara, M. Nishino, T. Kondo, and I. Kobayashi, "Moderate-intensity regular exercise decreases serum tumor necrosis factor- $\alpha$ and $\mathrm{HbA}_{1 \mathrm{c}}$ levels in healthy women," International Journal of Obesity, vol. 24, no. 9, pp. 1207-1211, 2000.

[92] K. M. Huffman, C. A. Slentz, C. W. Bales, J. A. Houmard, and W. E. Kraus, "Relationships between adipose tissue and cytokine responses to a randomized controlled exercise training intervention," Metabolism, vol. 57, no. 4, pp. 577583, 2008.

[93] L. Leick, B. Lindegaard, D. Stensvold, P. Plomgaard, B. Saltin, and H. Pilegaard, "Adipose tissue interleukin-18 mRNA and plasma interleukin-18: effect of obesity and exercise," Obesity, vol. 15, no. 2, pp. 356-363, 2007.

[94] M.-P. St-Onge, R. Desmond, G. Hunter, and B. Gower, "Baseline inflammatory markers do not modulate the lipid response to weight loss," Metabolism, vol. 57, no. 5, pp. 598604, 2008.

[95] W. H.-H. Sheu, T.-M. Chang, W.-J. Lee, et al., "Effect of weight loss on proinflammatory state of mononuclear cells in obese women," Obesity, vol. 16, no. 5, pp. 1033-1038, 2008.

[96] A. Dvorakova-Lorenzova, P. Suchanek, P. J. Havel, et al., "The decrease in C-reactive protein concentration after diet and physical activity induced weight reduction is associated with changes in plasma lipids, but not interleukin-6 or adiponectin," Metabolism, vol. 55, no. 3, pp. 359-365, 2006.

[97] L. U. Monzillo, O. Hamdy, E. S. Horton, et al., "Effect of lifestyle modification on adipokine levels in obese subjects with insulin resistance," Obesity Research, vol. 11, no. 9, pp. 1048-1054, 2003.

[98] D. T. Villareal, B. V. Miller III, M. Banks, L. Fontana, D. R. Sinacore, and S. Klein, "Effect of lifestyle intervention on metabolic coronary heart disease risk factors in obese older adults," American Journal of Clinical Nutrition, vol. 84, no. 6, pp. 1317-1323, 2006.

[99] T. O. Obisesan, C. Leeuwenburgh, T. Phillips, et al., "Creactive protein genotypes affect baseline, but not exercise training-induced changes, in C-reactive protein levels," Arteriosclerosis, Thrombosis, and Vascular Biology, vol. 24, no. 10, pp. 1874-1879, 2004.

[100] K. Esposito, F. Giugliano, C. Di Palo, et al., "Effect of lifestyle changes on erectile dysfunction in obese men: a randomized controlled trial," Journal of the American Medical Association, vol. 291, no. 24, pp. 2978-2984, 2004.

[101] R. Marfella, K. Esposito, M. Siniscalchi, et al., "Effect of weight loss on cardiac synchronization and proinflammatory cytokines in premenopausal obese women," Diabetes Care, vol. 27, no. 1, pp. 47-52, 2004.

[102] K. Esposito, A. Pontillo, C. Di Palo, et al., "Effect of weight loss and lifestyle changes on vascular inflammatory markers in obese women: a randomized trial," Journal of the American Medical Association, vol. 289, no. 14, pp. 1799-1804, 2003.
[103] K. Esposito, A. Pontillo, F. Giugliano, et al., "Association of low interleukin-10 levels with the metabolic syndrome in obese women," Journal of Clinical Endocrinology and Metabolism, vol. 88, no. 3, pp. 1055-1058, 2003.

[104] H. Ito, A. Ohshima, M. Inoue, et al., "Weight reduction decreases soluble cellular adhesion molecules in obese women," Clinical and Experimental Pharmacology and Physiology, vol. 29, no. 5-6, pp. 399-404, 2002.

[105] B. Zahorska-Markiewicz, M. Olszanecka-Glinianowicz, J. Janowska, and P. Kocelak, "The effect of weight loss on serum concentrations of FAS and tumour necrosis factor alpha in obese women," Endokrynologia Polska, vol. 59, no. 1, pp. 18$22,2008$.

[106] J. M. Bruun, B. Stallknecht, J. W. Helge, and B. Richelsen, "Interleukin-18 in plasma and adipose tissue: effects of obesity, insulin resistance, and weight loss," European Journal of Endocrinology, vol. 157, pp. 465-471, 2007.

[107] M. Olszanecka-Glinianowicz, B. Zahorska-Markiewicz, P. Kocelak, J. Janowska, M. Holecki, and E. Semik-Grabarczyk, "The effect of weight loss on serum concentration of interleukine-6 (IL-6) and insulin resistance," Endokrynologia Polska, vol. 57, no. 2, pp. 131-135, 2006.

[108] B. Zahorska-Markiewicz, K. Mizia-Stec, M. OlszaneckaGlinianowicz, and J. Janowska, "Effect of weight reduction on serum ghrelin and TNF $\alpha$ concentrations in obese women," European Journal of Internal Medicine, vol. 15, no. 3, pp. 172175, 2004.

[109] M. Olszanecka-Glinianowicz, B. Zahorska-Markiewicz, P. Kocelak, J. Janowska, and E. Semik-Grabarczyk, "The effect of weight loss on inflammation in obese women with polycystic ovary syndrome," Endokrynologia Polska, vol. 59, no. 1, pp. 13-17, 2008.

[110] J. Salas-Salvadó, M. Bulló, P. García-Lorda, et al., "Subcutaneous adipose tissue cytokine production is not responsible for the restoration of systemic inflammation markers during weight loss," International Journal of Obesity, vol. 30, no. 12, pp. 1714-1720, 2006.

[111] K. Esposito, R. Marfella, M. Ciotola, et al., "Effect of a Mediterranean-style diet on endothelial dysfunction and markers of vascular inflammation in the metabolic syndrome: a randomized trial," Journal of the American Medical Association, vol. 292, no. 12, pp. 1440-1446, 2004.

[112] A. S. Ryan and B. J. Nicklas, "Reductions in plasma cytokine levels with weight loss improve insulin sensitivity in overweight and obese postmenopausal women," Diabetes Care, vol. 27, no. 7, pp. 1699-1705, 2004.

[113] J. M. Bruun, J. W. Helge, B. Richelsen, and B. Stallknecht, "Diet and exercise reduce low-grade inflammation and macrophage infiltration in adipose tissue but not in skeletal muscle in severely obese subjects," American Journal of Physiology, vol. 290, no. 5, pp. E961-E967, 2006.

[114] T. S. Church, M. S. Willis, E. L. Priest, et al., "Obesity, macrophage migration inhibitory factor, and weight loss," International Journal of Obesity, vol. 29, no. 6, pp. 675-681, 2005.

[115] B. J. Nicklas, W. Ambrosius, S. P. Messier, et al., "Dietinduced weight loss, exercise, and chronic inflammation in older, obese adults: a randomized controlled clinical trial," American Journal of Clinical Nutrition, vol. 79, no. 4, pp. 544551, 2004.

[116] T. You, D. M. Berman, A. S. Ryan, and B. J. Nicklas, "Effects of hypocaloric diet and exercise training on inflammation 
and adipocyte lipolysis in obese postmenopausal women," Journal of Clinical Endocrinology and Metabolism, vol. 89, no. 4, pp. 1739-1746, 2004.

[117] M. H. Rokling-Andersen, J. E. Reseland, M. B. Veierod, et al., "Effects of long-term exercise and diet intervention on plasma adipokine concentrations," American Journal of Clinical Nutrition, vol. 86, no. 5, pp. 1293-1301, 2007.

[118] I. Giannopoulou, B. Fernhall, R. Carhart, et al., "Effects of diet and/or exercise on the adipocytokine and inflammatory cytokine levels of postmenopausal women with type 2 diabetes," Metabolism, vol. 54, no. 7, pp. 866-875, 2005.

[119] L. J. Aronne, "Therapeutic options for modifying cardiometabolic risk factors," American Journal of Medicine, vol. 120, no. 3, supplement 1, pp. S26-S34, 2007.

[120] D. Rucker, R. Padwal, S. K. Li, C. Curioni, and D. C. W. Lau, "Long term pharmacotherapy for obesity and overweight: updated meta-analysis," British Medical Journal, vol. 335, no. 7631, pp. 1194-1199, 2007.

[121] A. Hatzitolios, C. Savopoulos, G. Lazaraki, et al., "Efficacy of omega-3 fatty acids, atorvastatin and orlistat in nonalcoholic fatty liver disease with dyslipidemia," Indian Journal of Gastroenterology, vol. 23, no. 4, pp. 131-134, 2004.

[122] J. S. Torgerson, J. Hauptman, M. N. Boldrin, and L. Sjöström, "XENical in the prevention of diabetes in obese subjects (XENDOS) study: a randomized study of orlistat as an adjunct to lifestyle changes for the prevention of type 2 diabetes in obese patients," Diabetes Care, vol. 27, no. 1, pp. 155-161, 2004.

[123] M. Bougoulia, A. Triantos, and G. Koliakos, "Effect of weight loss with or without orlistat treatment on adipocytokines, inflammation, and oxidative markers in obese women," Hormones, vol. 5, no. 4, pp. 259-269, 2006.

[124] D. Yesilbursa, A. Serdar, Y. Heper, et al., "The effect of orlistatinduced weight loss on interleukin- 6 and C-reactive protein levels in obese subjects," Acta Cardiologica, vol. 60, no. 3, pp. 265-269, 2005.

[125] C.-J. Hsieh, P.-W. Wang, R.-T. Liu, et al., "Orlistat for obesity: benefits beyond weight loss," Diabetes Research and Clinical Practice, vol. 67, no. 1, pp. 78-83, 2005.

[126] R. D. Brook, R. L. Bard, L. Glazewski, et al., "Effect of short-term weight loss on the metabolic syndrome and conduit vascular endothelial function in overweight adults," American Journal of Cardiology, vol. 93, no. 8, pp. 1012-1016, 2004.

[127] R. L. Borges, F. F. Ribeiro-Filho, K. M. B. Carvalho, and M. T. Zanella, "Impact of weight loss on adipocytokines, C-reactive protein and insulin sensitivity in hypertensive women with central obesity," Arquivos Brasileiros de Cardiologia, vol. 89, no. 6, pp. 409-414, 2007.

[128] E. L. Madsen, A. Rissanen, J. M. Bruun, et al., "Weight loss larger than $10 \%$ is needed for general improvement of levels of circulating adiponectin and markers of inflammation in obese subjects: a 3-year weight loss study," European Journal of Endocrinology, vol. 158, no. 2, pp. 179-187, 2008.

[129] L. Samuelsson, A. Gottsäter, and F. Lindgärde, "Decreasing levels of tumour necrosis factor $\alpha$ and interleukin 6 during lowering of body mass index with orlistat or placebo in obese subjects with cardiovascular risk factors," Diabetes, Obesity and Metabolism, vol. 5, no. 3, pp. 195-201, 2003.

[130] K. Tziomalos, G. E. Krassas, and T. Tzotzas, "The use of sibutramine in the management of obesity and related disorders: an update," Vascular Health and Risk Management, vol. 5, pp. 441-452, 2009.
[131] G. A. Bray and F. L. Greenway, "Pharmacological treatment of the overweight patient," Pharmacological Reviews, vol. 59, no. 2, pp. 151-184, 2007.

[132] M. Shechter, R. Beigel, D. Freimark, S. Matetzky, and M. S. Feinberg, "Short-term sibutramine therapy is associated with weight loss and improved endothelial function in obese patients with coronary artery disease," American Journal of Cardiology, vol. 97, no. 11, pp. 1650-1653, 2006.

[133] G. Valsamakis, P. G. McTernan, R. Chetty, et al., "Modest weight loss and reduction in waist circumference after medical treatment are associated with favorable changes in serum adipocytokines," Metabolism, vol. 53, no. 4, pp. 430434, 2004.

[134] S. H. Jung, H. S. Park, K.-S. Kim, et al., "Effect of weight loss on some serum cytokines in human obesity: increase in IL-10 after weight loss," Journal of Nutritional Biochemistry, vol. 19, no. 6, pp. 371-375, 2008.

[135] Y.-J. Hung, Y.-C. Chen, D. Pei, et al., "Sibutramine improves insulin sensitivity without alteration of serum adiponectin in obese subjects with type 2 diabetes," Diabetic Medicine, vol. 22, no. 8, pp. 1024-1030, 2005.

[136] D. M. Nathan, J. B. Buse, M. B. Davidson, et al., "Medical management of hyperglycemia in type 2 diabetes: a consensus algorithm for the initiation and adjustment of therapya consensus statement of the American Diabetes Association and the European Association for the Study of Diabetes," Clinical Diabetes, vol. 27, no. 1, pp. 4-16, 2009.

[137] R. S. Hundal and S. E. Inzucchi, "Metformin: new understandings, new uses," Drugs, vol. 63, no. 18, pp. 1879-1894, 2003.

[138] F. Abbasi, J. W. Chu, T. McLaughlin, C. Lamendola, E. T. Leary, and G. M. Reaven, "Effect of metformin treatment on multiple cardiovascular disease risk factors in patients with type 2 diabetes mellitus," Metabolism, vol. 53, no. 2, pp. 159164, 2004.

[139] S. S. Lund, L. Tarnow, C. D. A. Stehouwer, et al., "Impact of metformin versus repaglinide on non-glycaemic cardiovascular risk markers related to inflammation and endothelial dysfunction in non-obese patients with type 2 diabetes," European Journal of Endocrinology, vol. 158, no. 5, pp. 631$641,2008$.

[140] J. De Jager, A. Kooy, P. Lehert, et al., "Effects of shortterm treatment with metformin on markers of endothelial function and inflammatory activity in type 2 diabetes mellitus: a randomized, placebo-controlled trial," Journal of Internal Medicine, vol. 257, no. 1, pp. 100-109, 2005.

[141] N. V. Chu, A. P. S. Kong, D. D. Kim, et al., "Differential effects of metformin and troglitazone on cardiovascular risk factors in patients with type 2 diabetes," Diabetes Care, vol. 25, no. 3, pp. 542-549, 2002.

[142] A. Eriksson, S. Attvall, M. Bonnier, J. W. Eriksson, B. Rosander, and F. A. Karlsson, "Short-term effects of metformin in type 2 diabetes," Diabetes, Obesity and Metabolism, vol. 9, no. 3, pp. 330-336, 2007.

[143] N. Katsiki, E. Georgiadou, and A. I. Hatzitolios, "The role of insulin-sensitizing agents in the treatment of polycystic ovary syndrome," Drugs, vol. 69, no. 11, pp. 1417-1431, 2009.

[144] T. Tsilchorozidou, V. Mohamed-Ali, and G. S. Conway, "Determinants of interleukin-6 and C-reactive protein vary in polycystic ovary syndrome, as do effects of short- and long-term metformin therapy," Hormone Research, vol. 71, no. 3, pp. 148-154, 2009. 
[145] J. Jakubowska, A. Bohdanowicz-Pawlak, A. Milewicz, J. Szymczak, G. Bednarek-Tupikowska, and M. Demissie, "Plasma cytokines in obese women with polycystic ovary syndrome, before and after metformin treatment," Gynecological Endocrinology, vol. 24, no. 7, pp. 378-384, 2008.

[146] E. Diamanti-Kandarakis, T. Paterakis, K. Alexandraki, et al., "Indices of low-grade chronic inflammation in polycystic ovary syndrome and the beneficial effect of metformin," Human Reproduction, vol. 21, no. 6, pp. 1426-1431, 2006.

[147] R. Sari, E. Eray, S. Ozdem, H. Akbas, and E. Coban, "Comparison of the effects of sibutramine versus sibutramine plus metformin in obese women," Clinical and Experimental Medicine. In press.

[148] M. J. F. Bult, T. van Dalen, and A. F. Muller, "Surgical treatment of obesity," European Journal of Endocrinology, vol. 158, no. 2, pp. 135-145, 2008.

[149] H. Buchwald, Y. Avidor, E. Braunwald, et al., "Bariatric surgery: a systematic review and meta-analysis," Journal of the American Medical Association, vol. 292, no. 14, pp. 17241737, 2004.

[150] T. D. Adams, R. E. Gress, S. C. Smith, et al., "Long-term mortality after gastric bypass surgery," The New England Journal of Medicine, vol. 357, no. 8, pp. 753-761, 2007.

[151] D. R. Flum and E. P. Dellinger, "Impact of gastric bypass operation on survival: a population-based analysis," Journal of the American College of Surgeons, vol. 199, no. 4, pp. 543551, 2004.

[152] N. V. Christou, J. S. Sampalis, M. Liberman, et al., "Surgery decreases long-term mortality, morbidity, and health care use in morbidly obese patients," Annals of Surgery, vol. 240, no. 3, pp. 416-424, 2004.

[153] L. Sjöström, K. Narbro, C. D. Sjöström, et al., "Effects of bariatric surgery on mortality in Swedish obese subjects," The New England Journal of Medicine, vol. 357, no. 8, pp. 741-752, 2007.

[154] N. T. Nguyen, J. A. Slone, X.-M. T. Nguyen, J. S. Hartman, and D. B. Hoyt, "A prospective randomized trial of laparoscopic gastric bypass versus laparoscopic adjustable gastric banding for the treatment of morbid obesity: outcomes, quality of life, and costs," Annals of Surgery, vol. 250, no. 4, pp. 631-639, 2009.

[155] L. Angrisani, M. Lorenzo, and V. Borrelli, "Laparoscopic adjustable gastric banding versus Roux-en-Y gastric bypass: 5-year results of a prospective randomized trial," Surgery for Obesity and Related Diseases, vol. 3, no. 2, pp. 127-132, 2007.

[156] M. A. Maggard, L. R. Shugarman, M. Suttorp, et al., "Metaanalysis: surgical treatment of obesity," Annals of Internal Medicine, vol. 142, no. 7, pp. 547-559, 2005.

[157] L. Sjöström, A.-K. Lindroos, M. Peltonen, et al., "Lifestyle, diabetes, and cardiovascular risk factors 10 years after bariatric surgery," The New England Journal of Medicine, vol. 351, no. 26, pp. 2683-2693, 2004.

[158] S.-B. Chen, Y.-C. Lee, K.-H. Ser, et al., "Serum C-reactive protein and white blood cell count in morbidly obese surgical patients," Obesity Surgery, vol. 19, no. 4, pp. 461-466, 2009.

[159] P. Habib, J. D. Scrocco, M. Terek, V. Vanek, and J. R. Mikolich, "Effects of bariatric surgery on inflammatory, functional and structural markers of coronary atherosclerosis," American Journal of Cardiology, vol. 104, no. 9, pp. 1251-1255, 2009.

[160] C. F. Emery, M. D. M. Fondow, C. M. Schneider, et al., "Gastric bypass surgery is associated with reduced inflammation and less depression: a preliminary investigation," Obesity Surgery, vol. 17, no. 6, pp. 759-763, 2007.
[161] S. M. Zagorski, N. N. Papa, and M. H. Chung, "The effect of weight loss after gastric bypass on C-reactive protein levels," Surgery for Obesity and Related Diseases, vol. 1, no. 2, pp. 8185, 2005.

[162] N. Gletsu, E. Lin, L. Khaitan, et al., "Changes in C-reactive protein predict insulin sensitivity in severely obese individuals after weight loss surgery," Journal of Gastrointestinal Surgery, vol. 9, no. 8, pp. 1119-1128, 2005.

[163] C. Holdstock, L. Lind, B. E. Engstrom, et al., "CRP reduction following gastric bypass surgery is most pronounced in insulin-sensitive subjects," International Journal of Obesity, vol. 29, no. 10, pp. 1275-1280, 2005.

[164] V. Agrawal, K. R. Krause, D. L. Chengelis, K. C. Zalesin, L. L. Rocher, and P. A. McCullough, "Relation between degree of weight loss after bariatric surgery and reduction in albuminuria and C-reactive protein," Surgery for Obesity and Related Diseases, vol. 5, no. 1, pp. 20-26, 2009.

[165] E. Lin, L. S. Phillips, T. R. Ziegler, et al., "Increases in adiponectin predict improved liver, but not peripheral, insulin sensitivity in severely obese women during weight loss," Diabetes, vol. 56, no. 3, pp. 735-742, 2007.

[166] L. A. Vazquez, F. Pazos, J. R. Berrazueta, et al., "Effects of changes in body weight and insulin resistance on inflammation and endothelial function in morbid obesity after bariatric surgery," Journal of Clinical Endocrinology and Metabolism, vol. 90, no. 1, pp. 316-322, 2005.

[167] N. Vilarrasa, J. Vendrell, R. Sanchez-Santos, et al., "Effect of weight loss induced by gastric bypass on proinflammatory interleukin-18, soluble tumour necrosis factor- $\alpha$ receptors, C-reactive protein and adiponectin in morbidly obese patients," Clinical Endocrinology, vol. 67, no. 5, pp. 679-686, 2007.

[168] M. Shargorodsky, A. Fleed, M. Boaz, D. Gavish, and R. Zimlichman, "The effect of a rapid weight loss induced by laparoscopic adjustable gastric banding on arterial stiffness, metabolic and inflammatory parameters in patients with morbid obesity," International Journal of Obesity, vol. 30, no. 11, pp. 1632-1638, 2006.

[169] M. Laimer, S. Kaser, M. Kranebitter, et al., "Effect of pronounced weight loss on the nontraditional cardiovascular risk marker matrix metalloproteinase-9 in middle-aged morbidly obese women," International Journal of Obesity, vol. 29, no. 5, pp. 498-501, 2005.

[170] F. M. H. van Dielen, W. A. Buurman, M. Hadfoune, J. Nijhuis, and J. W. Greve, "Macrophage inhibitory factor, plasminogen activator inhibitor-1, other acute phase proteins, and inflammatory mediators normalize as a result of weight loss in morbidly obese subjects treated with gastric restrictive surgery," Journal of Clinical Endocrinology and Metabolism, vol. 89, no. 8, pp. 4062-4068, 2004.

[171] C. W. Kopp, H.-P. Kopp, S. Steiner, et al., "Weight loss reduces tissue factor in morbidly obese patients," Obesity Research, vol. 11, no. 8, pp. 950-956, 2003.

[172] H. P. Kopp, C. W. Kopp, A. Festa, et al., "Impact of weight loss on inflammatory proteins and their association with the insulin resistance syndrome in morbidly obese patients," Arteriosclerosis, Thrombosis, and Vascular Biology, vol. 23, no. 6, pp. 1042-1047, 2003.

[173] U. Hanusch-Enserer, E. Cauza, M. Spak, et al., "Acutephase response and immunological markers in morbid obese patients and patients following adjustable gastric banding," International Journal of Obesity, vol. 27, no. 3, pp. 355-361, 2003. 
[174] M. Laimer, C. F. Ebenbichler, S. Kaser, et al., "Markers of chronic inflammation and obesity: a prospective study on the reversibility of this association in middle-aged women undergoing weight loss by surgical intervention," International Journal of Obesity, vol. 26, no. 5, pp. 659-662, 2002.

[175] J. F. Carroll, S. F. Franks, A. B. Smith, and D. R. Phelps, "Visceral adipose tissue loss and insulin resistance 6 months after laparoscopic gastric banding surgery: a preliminary study," Obesity Surgery, vol. 19, no. 1, pp. 47-55, 2009.

[176] U. Hanusch-Enserer, G. Zorn, J. Wojta, et al., "Nonconventional markers of atherosclerosis before and after gastric banding surgery," European Heart Journal, vol. 30, no. 12, pp. 1516-1524, 2009.

[177] M. Manco, J. M. Fernandez-Real, F. Equitani, et al., "Effect of massive weight loss on inflammatory adipocytokines and the innate immune system in morbidly obese women," Journal of Clinical Endocrinology and Metabolism, vol. 92, no. 2, pp. 483-490, 2007.

[178] H. A. Hakeam, P. J. O’Regan, A. M. Salem, F. Y. Bamehriz, and L. F. Jomaa, "Inhibition of C-reactive protein in morbidly obese patients after laparoscopic sleeve gastrectomy," Obesity surgery, vol. 19, no. 4, pp. 456-460, 2009.

[179] L.-Y. Lin, W.-J. Lee, H.-N. Shen, et al., "Nitric oxide production is paradoxically decreased after weight reduction surgery in morbid obesity patients," Atherosclerosis, vol. 190, no. 2, pp. 436-442, 2007.

[180] G.-H. Schernthaner, H.-P. Kopp, S. Kriwanek, et al., "Effect of massive weight loss induced by bariatric surgery on serum levels of interleukin-18 and monocyte-chemoattractantprotein-1 in morbid obesity," Obesity Surgery, vol. 16, no. 6, pp. 709-715, 2006.

[181] J. Nijhuis, F. M. H. van Dielen, S. M. G. Fouraschen, et al., "Endothelial activation markers and their key regulators after restrictive bariatric surgery," Obesity, vol. 15, no. 6, pp. 13951399, 2007.

[182] A. E. Pontiroli, P. Pizzocri, R. Paroni, and F. Folli, "Sympathetic overactivity, endothelial dysfunction, inflammation, and metabolic abnormalities cluster in grade III (World Health Organization) obesity: reversal through sustained weight loss obtained with laparoscopic adjustable gastric banding," Diabetes Care, vol. 29, no. 12, pp. 2735-2738, 2006.

[183] J. Ybarra, F. Blanco-Vaca, S. Fernandez, et al., "The effects of liposuction removal of subcutaneous abdominal fat on lipid metabolism are independent of insulin sensitivity in normaloverweight individuals," Obesity Surgery, vol. 18, no. 4, pp. 408-414, 2008.

[184] S. Klein, L. Fontana, L. Young, et al., "Absence of an effect of liposuction on insulin action and risk factors for coronary heart disease," The New England Journal of Medicine, vol. 350, no. 25, pp. 2549-2557, 2004.

[185] G. Giugliano, G. Nicoletti, E. Grella, et al., "Effect of liposuction on insulin resistance and vascular inflammatory markers in obese women," British Journal of Plastic Surgery, vol. 57, no. 3, pp. 190-194, 2004.

[186] E. Selvin, N. P. Paynter, and T. P. Erlinger, "The effect of weight loss on C-reactive protein: a systematic review," Archives of Internal Medicine, vol. 167, no. 1, pp. 31-39, 2007.

[187] P. M. Ridker, E. Danielson, F. A. Fonseca, et al., "Reduction in C-reactive protein and LDL cholesterol and cardiovascular event rates after initiation of rosuvastatin: a prospective study of the JUPITER trial," The Lancet, vol. 373, no. 9670, pp. 1175-1182, 2009.
[188] D. A. Morrow, J. A. de Lemos, M. S. Sabatine, et al., "Clinical relevance of C-reactive protein during follow-up of patients with acute coronary syndromes in the Aggrastat-to-Zocor Trial," Circulation, vol. 114, no. 4, pp. 281-288, 2006.

[189] P. M. Ridker, C. P. Cannon, D. Morrow, et al., "C-reactive protein levels and outcomes after statin therapy," The New England Journal of Medicine, vol. 352, no. 1, pp. 20-28, 2005. 


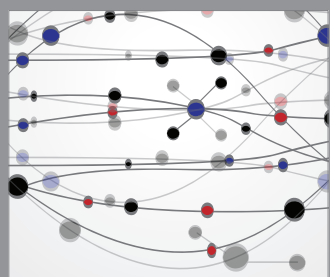

The Scientific World Journal
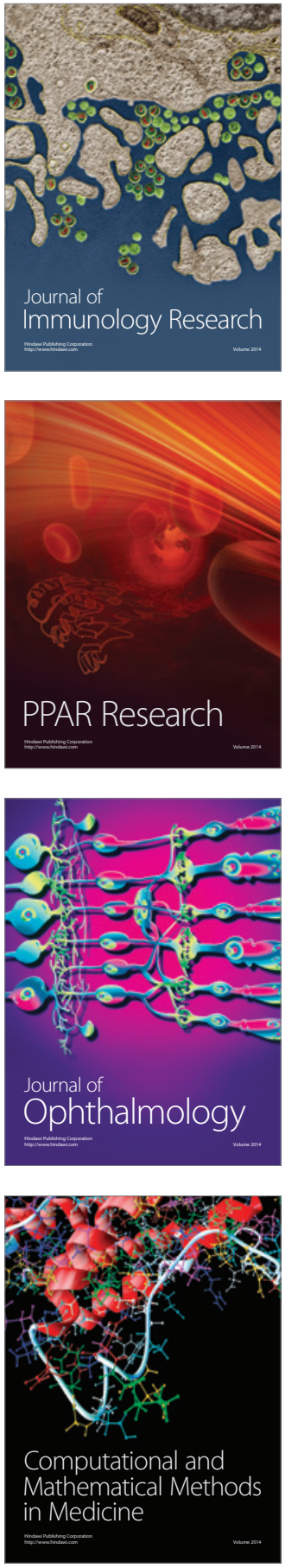

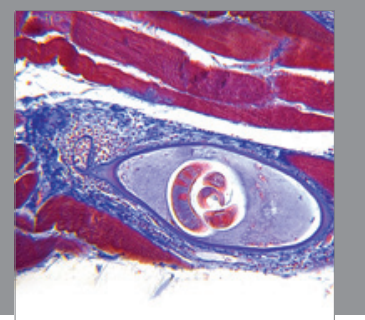

Gastroenterology

Research and Practice
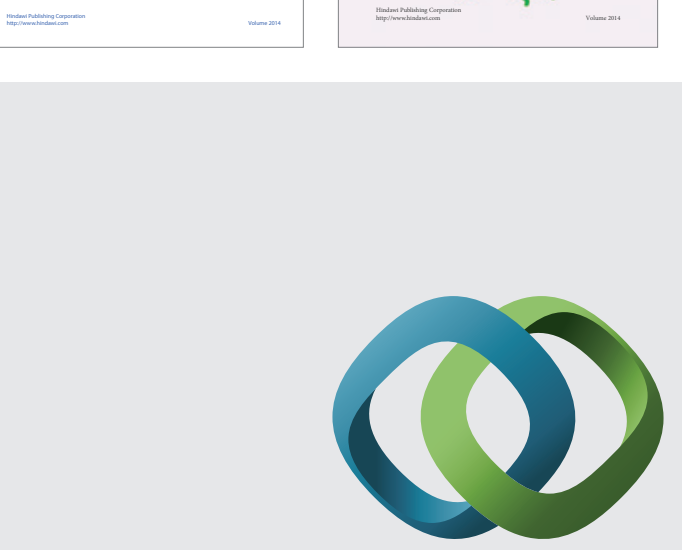

\section{Hindawi}

Submit your manuscripts at

http://www.hindawi.com
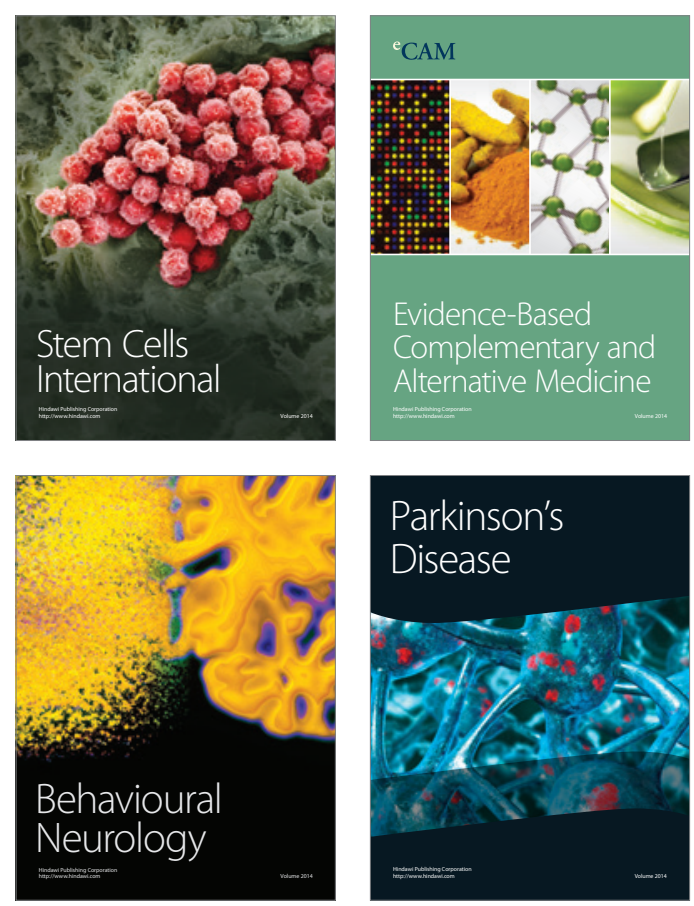

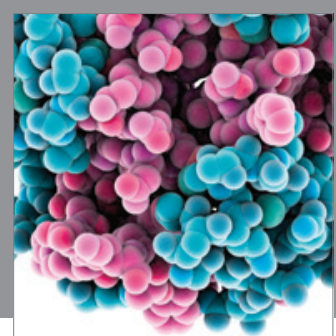

Journal of
Diabetes Research

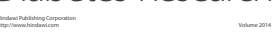

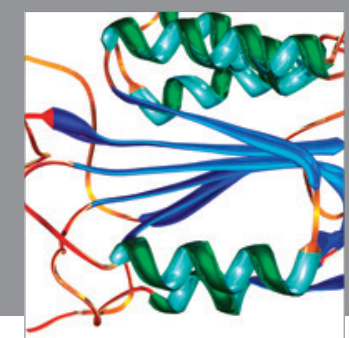

Disease Markers
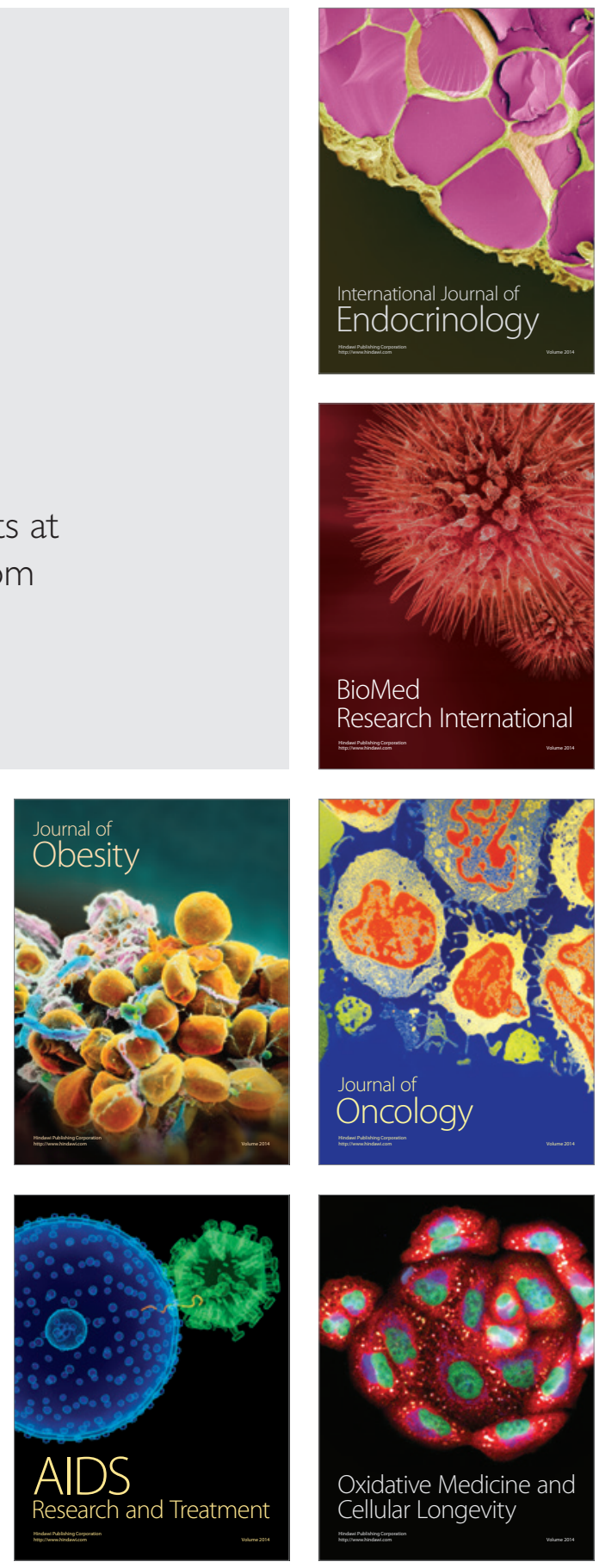